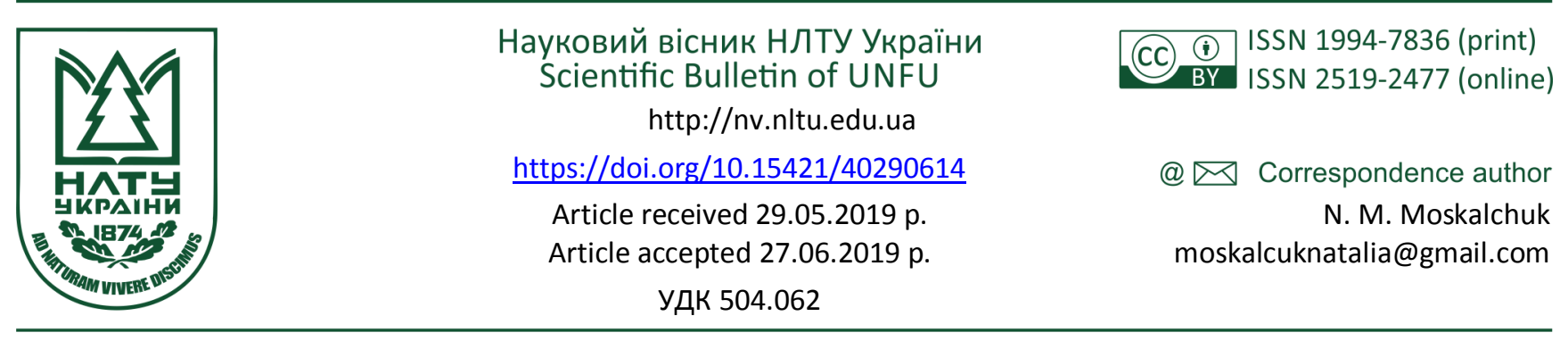

Н. М. Москальчук, Я. О. Адаменко

Івано-Франківський національний технічний університет нафти і газу, м. Івано-Франківськ, Україна

\title{
ВИБІР МАЙДАНЧИКА ДЛЯ РОЗТАШУВАННЯ ВІТРОЕЛЕКТРОСТАНЦІЙ НА ПІДСТАВІ ГІС-ПІДХОДУ
}

\begin{abstract}
Запропоновано алгоритм вибору майданчика для розташування вітроелектростанцій (BEC) шляхом застосування ГІСпідходу, який містить, по-перше, вибір досліджуваної території зі сприятливими кліматичними умовами за результатами оцінки вітроенергетичного потенціалу; по-друге, врахування на досліджуваній території геопросторових обмежень шляхом збирання даних, їх аналізу та побудови карт компонентів довкілля, які можуть впливати чи зазнавати впливу від ВЕС, встановлення критеріїв геопросторових обмежень та їх графічного представлення у вигляді покомпонентних карт орографічних, технічних, екологічних обмежень та комплексної карти геопросторових обмежень; по-третє, виділення перспективних майданчиків розташування ВЕС шляхом накладання карт перспективних швидкостей вітру на заданій висоті та карти геопросторових обмежень. Теоретично обгрунтовано врахування трьох типів обмежень: орографічних, технічних (дорожньої мережі та енергомережі) та природних екологічних (природно-заповідного фонду (ПЗФ), водні об'єкти, ліси) і соціально-економічних екологічних (населені пункти, аеродроми) обмежень шляхом встановлення геопросторових виключень та екологічно безпечних відстаней. Застосовано алгоритм геопросторового планування майданчика для розташування ВЕС для Івано-Франківської області. Побудовано комплексну карту геопросторових обмежень території зі сприятливими вітрокліматичними умовами. Побудовано карту перспективних майданчиків розташування ВЕС. Виділено 24 безпечні перспективні майданчики розташування ВЕС загальною площею 4514,22 га в межах досліджуваної території. На прикладі Vestas V112 3.3 МВт розраховано можливу потужність ВЕС на перспективних майданчиках, яка для 88 ВЕУ становила 290,4 МВт.

Ключові слова: ГІС-підхід; геопросторове планування; вітроенергетичний потенціал; геопросторові обмеження; вітроелектростанція (ВЕС).
\end{abstract}

Вступ. Основною вимогою до реалізації проектів 3 вітроенергетики є достатній вітроенергетичний потенціал території, проте, окрім сприятливих вітрокліматичних характеристик, важливим $є$ екологічно безпечне просторове планування 3 урахуванням обмежень, що дасть змогу уникнути перешкод запланованій діяльності, впливу на довкілля чи незадоволення громадськості.

В основу геопросторового планування з використанням ГІС-технологій поставлено виділення перспективних територій шляхом урахування сприятливих та обмежувальних чинників різного характеру з їх подальшим графічним накладанням. Виключення територій може грунтуватися на вимогах законодавства чи на наукових дослідженнях. Відсутність геопросторового планування може призвести до видачі висновку із оцінки впливу на довкілля (ОВД) про недопустимість провадження планованої діяльності через розміщення проекту на територіях природно-заповідного фонду (ПЗФ), водоохоронних зонах чи прибережних захисних смугах, де така діяльність заборонена.

Матеріал і методи дослідження. Для підвищення рівня екологічної безпеки використання енергії вітру запропоновано проведення геопросторового плануван-

ня майданчика для розташування вітроелектростанцій (BEC) на основі комплексу дій з оцінювання вітроенергетичного потенціалу і врахування орографічних, технічних та екологічних обмежень.

Послідовність дій 3 геопросторового планування запропоновано здійснювати згідно з алгоритмом вибору майданчика для розташування ВEC на основі ГІСпідходу (рис. 1).

Алгоритм вибору майданчика для розташування BEC містить, по-перше, вибір досліджуваної території зі сприятливими вітрокліматичними умовами за результатами оцінки вітроенергетичного потенціалу: розрахунку середньої швидкості вітру на заданій висоті, визначення перспективних швидкостей вітру, графічного представлення у вигляді карт середньої швидкості вітру та карт перспективних швидкостей вітру на заданій виcoтi.

Основним джерелом первинних даних для оцінки вітроенергетичного потенціалу є спостереження за вітровими характеристиками на державних гідрометеопостах, оскільки на них спостереження проводять за єдиною методикою, встановленою Всесвітньою метеорологічною організацією, вони охоплюють значні періоди і

Інформація про авторів:

Москальчук Наталія Михайлівна, асистент, кафедра екологіï. Email: moskalcuknatalia@gmail.com; https://orcid.org/0000-0003-4838-7972

Адаменко Ярослав Олегович, д-р техн. наук, професор, завідувач кафедри екології. Email: yarad1964@gmail.com; https://orcid.org/0000-0001-5665-7958

Цитування за ДСтУ: Москальчук Н. М., Адаменко Я. О. Вибір майданчика для розташування вітроелектростанцій на підставі ГІСпідходу. Науковий вісник НЛтУ України. 2019, т. 29, № 6. С. 71-75.

Citation APA: Moskalchuk, N. M. , \& Adamenko, Ya. O. (2019). The wind farm site selection on GIS-based approach. Scientific Bulletin of UNFU, 29(6), 71-75. https://doi.org/10.15421/40290614

Науковий вісник НЛТУ України, 2019, т. 29, № 6 Scientific Bulletin of UNFU, 2019, vol. 29, no 6 
$\epsilon$ величезною базою даних. Оцінювання кліматичних ресурсів вітрової енергії: статистична обробка метеорологічних даних, приведення швидкості вітру до висоти ВЕУ, розрахунок основних вітроенергетичних показників базуються на методичних вказівках для метеослужб, керівництвах для авіації, теорії вітроенергетики.

Геопросторові обмеження на досліджуваній території встановлюють шляхом збирання даних, їх аналізу та побудови карт компонентів довкілля, які можуть впливати чи зазнавати впливу від ВЕС (рельєф, дорожня та енерго-мережа, ПЗФ, водні об'єкти, ліси, населені пункти, аеропорти), застосування критеріїв геопросторових обмежень та їх графічного представлення у вигляді покомпонентних карт орографічних, технічних, екологічних обмежень та комплексної карти геопросторових обмежень; по-третє, виділення перспективних майданчиків розташування ВЕС шляхом накладання карт перспективних швидкостей вітру на заданій висоті та карти геопросторових обмежень.

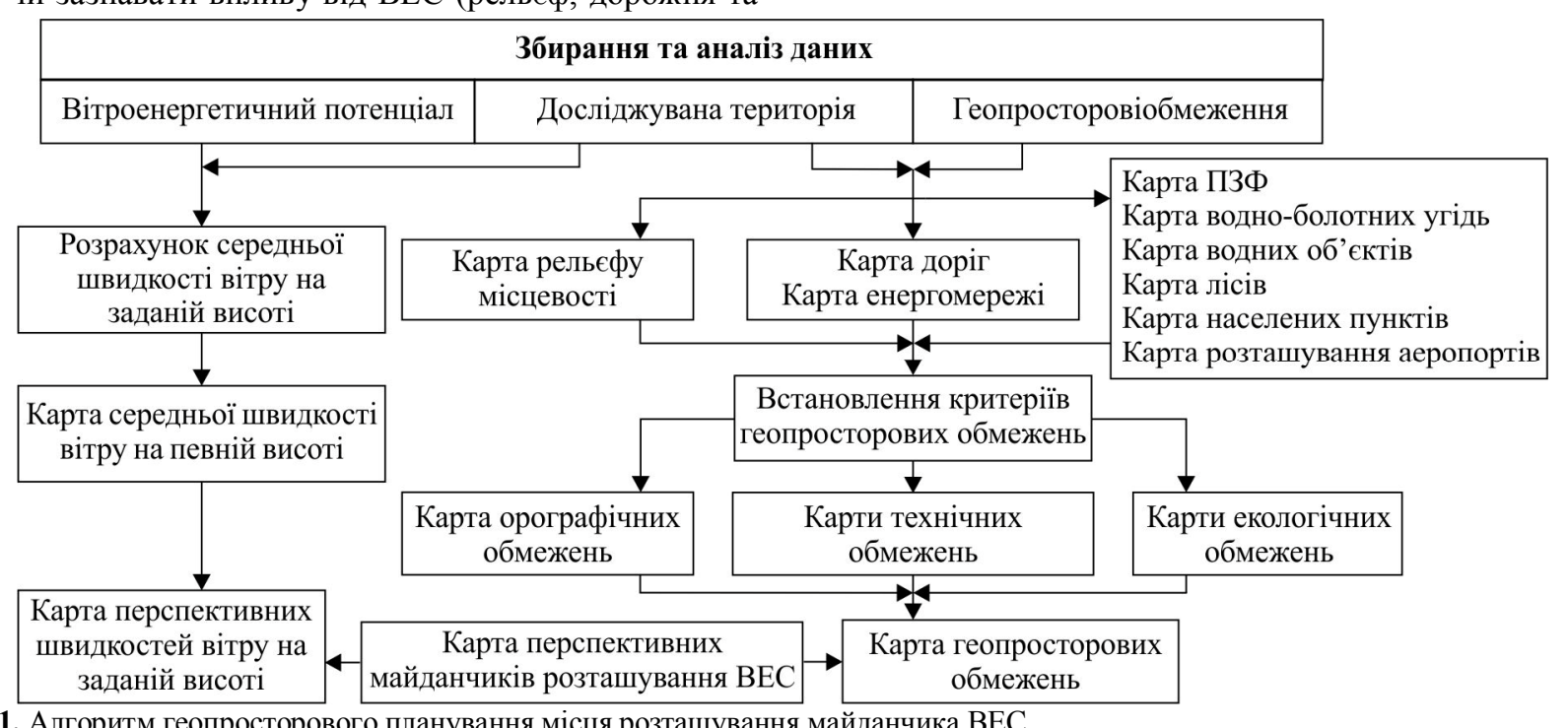

Рис. 1. Алгоритм геопросторового планування місця розташування майданчика ВЕС

Теоретично обгрунтовано врахування трьох типів обмежень: орографічних, технічних (дорожньої мережі та енергомережі) та природних екологічних (ПЗФ, водні об'єкти, ліси) і соціально-економічних екологічних (населені пункти, аеродроми) шляхом встановлення геопросторових виключень та екологічно безпечних відстаней.

Важливими орографічними обмеженнями є ухил території, який може впливати на можливість проведення будівництва ВЕС та виникнення небезпечних екзодинамічних процесів. На гірських схилах 3 крутизною від $20^{\circ}$ переважаючими схиломоделюючими процесами $є$ обвали, зсуви, селі, лавини (DBN V.1.1-24, 2009). Будівництво ВЕС на крутих схилах характеризується підвищеною складністю, що призводить до збільшення витрат та виникнення різноманітних матеріально-технічних проблем, зокрема будівництва під'їзих шляхів та фундаменту. 3 крутизною схилів корелюється виникнення зсувів - на схилах крутизною 15-20 ${ }^{\circ}$ зареєстровано найбільшу їх кількість (Kuzmenko et al., 2014).

Технічні обмеження - можливість доступу до майданчика та придатність до ведення будівництва та експлуатації. На території планованої ВЕС, зазвичай, передбачається будівництво технологічних проїздів та під'їзних доріг. Однак майданчики, які передбачають розчищення великих площ території для будівництва доріг, можуть виявитися економічно недоцільними. Це теж стосується і об'єктів об'єднаної енергетичної системи, майданчики розташовані на значній відстані від них вимагатимуть більших витрат.

Урахування екологічних обмежень під час вибору майданчика для розташування ВЕС дає змогу мінімізувати можливі негативні впливи та налагодити позитивні стосунки з місцевою громадою. На сьогодні українсь- ким законодавством не визначено санітарно-захисні зони (С33) ВЕС чи безпечні відстані від них.

Основним компонентом природного середовища, який зазнає впливу від ВЕС, є орнітофауна. Спорудження та експлуатація ВЕС може призводити до загибелі птахів та кажанів через зіткнення з ВЕУ, витіснення птахів 3 їх ареалів та впливати на міграцію птахів (Hötker, 2006). Спорудження ВЕС також негативно позначається на якості та естетичному вигляді ландшафтів та може призвести до зниження рекреаційної цінності території. Вибираючи майданчик розташування ВEC, повинні виключатись землі ПЗФ, оскільки на них законодавством України заборонено будь-яку діяльність, яка негативно впливає або може негативно впливати на стан природних та історико-культурних комплексів та об'єктів чи перешкоджає їх використанню за цільовим призначенням (Zakon Ukrainy, 2012). Поряд з землями ПЗФ запропоновано уникати водно-болотних угідь державного та міжнародного значення, які охороняються Рамсарською конвенцією, та перспективних угідь, які погоджені розпорядженнями Кабміну України і подані на розгляд, оскільки вони можуть бути місцями регулярного перебування водоплавних птахів (Ramsar 02.02.1971, 2013) та інших великих водних об'єктів (великі річки та їх притоки I порядку, середні річки, водосховища, озера). Залісені території - ще один природний екологічний компонент, який запропоновано виключати у виборі майданчика, оскільки ці екосистеми характеризуються високим біорізноманіттям і $є$ ареалами для птахів та кажанів. Оскільки близькість деревних насаджень створюватиме природні перешкоди вітру, розташування ВЕС на лісистій території вимагатиме вирубування, що призведе до значних впливів на довкілля. Також показники зіткнення кажанів з ВЕУ, які розташовані поблизу лісів, у рази вищі (Hötker, 2006). Окрім вик- 
лючення, важливим є дотримання певної відстані від ВЕС до об'єктів ПЗФ, водно-болотних угідь та лісів, оскільки природні території та види, що їх населяють, характеризуються високою чутливістю, а ліси, окрім цього, можуть створювати перешкоди вітру.

Головними чинниками впливу, які вимагають заборони розташування ВЕС на сільській і ландшафтно-рекреаційних територіях та дотримання безпечних відстаней від них, є візуальний вплив, шум, ефект тіні мерехтіння та розкидання льоду. Щодо розмірів С33, то ДСП 173-96 "Державні санітарні правила планування та забудови населених пунктів" (DSP 173-96, 2013) вимагають встановлення розмірів С33 на основі розрахунку концентрації в атмосферному повітрі шкідливих речовин, які $є$ у викидах підприємств, розрахунку рівнів шуму та електромагнітних випромінювань 3 урахуванням реальної санітарної ситуації, а також даних лабораторних досліджень щодо аналогічних діючих підприємств та об'єктів. В Україні немає норм щодо розмірів територій, які зазнають візуального впливу від ВЕС. У розрахунку С33 його не враховують. Закордонними дослідженнями підтверджено, що на невеликій відстані (менше 1000 м) ВЕУ перевищують зріст людини і можуть чинити тиск та бути небажаними для спостерігачів, на відстані 1-5 км можуть мати вплив на ландшафт (A Guideline Report, 2012). Шум від ВEC, рівні якого в межах населених пунктів нормуються ДБН В.1.131:2013 "Захист територій, будинків і споруд від шуму" (DBN V.1.1-31, 2013), залежить від звукової потужності вітроелектричної установки (ВЕУ), яка своєю чергою залежить від швидкості вітру, висоти ВЕУ, особливостей місцевості i, як правило, досягає нормативних значень нічного часу для територій житлової забудови у 45 дБА на відстані 400-500 м. Ефект мерехтіння тіні виникає, коли лопаті ротора турбіни, обертаючись, періодично відкидають тінь на прилеглі житлові об'єкти, яка є видимою через отвори в будівлі, найчастіше - вікна, цей вплив може відчуватись на відстані до 1 км (Ваse Final Report, 2014). За від'ємної температури повітря на лопатях ВЕУ може утворюватися лід, який може відколюватись і падати, що може бути причиною травм. Найважчі частини до 10 кг падають біля самої турбіни, а легші фрагменти можуть бути віднесені на відстань до 600 м (Turbine blades, 2014). Зазвичай, таке відбувається за екстремально низьких температур, кілька днів на рік. Щодо впливу на цивільну та військову авіацію, в Україні немає чітких норм щодо віддаленості ВEC від аеропортів. У "Повітряному кодексі України" прописано, що будівлі і природні об'єкти, розташовані на приаеродромній території, не повинні становити загрози для польотів повітряних суден (Uhiddia Ukrainy, 2019). Розміри приаеродромної території залежать від класу аеродрому і складають коло з радіусом від 2,5 км злітно-посадкових майданчиків до 50 км для аеродромів класів А, Б, В, Г.

Унаслідок узагальнення даних щодо компонентів довкілля, які можуть впливати чи зазнавати впливу від $\mathrm{BEC}$, запропоновано під час геопросторового планування виключати території, які мають:

- ухил більше $25 \%$;

- відстань до дорожньої мережі більше 3 км;

- відстань до енергомережі більше 5 км;

- відстань до заповідників менше 1000 м,

- інших територій та об'єктів ПЗФ менше 400 м;
• відстань до водно-болотних угідь менше 1000 м;

- відстань до великих та середніх річок, озер, водосховищ, ставків від 3 га менше 400 м;

- відстань до лісів менше 400 м;

- відстань до сельбищних та рекреаційні територій населених пунктів менше 1000 м;

- відстань до аеродромів менше 10 км.

Використання ГІС-підходу полягало у застосуванні програмних продуктів Surfer, Mapinfo, GoogleEarth для побудови карт швидкості вітру на різних висотах, карт геопросторових обмежень та карти перспективних майданчиків розташування ВEC шляхом накладання карт перспективних швидкостей вітру на заданій висоті та карти геопросторових обмежень.

Результати дослідження. Застосовано алгоритм геопросторового планування майданчика для розташування ВЕС для Івано-Франківської обл.

На основі оцінки вітроенергетичного потенціалу Івано-Франківської обл. з'ясовано, що найсприятливіші кліматичні умови для промислової вітроенергетики є у гірських районах Українських Карпат та Передкарпатті; ВЕУ середньої потужності доцільно розташовувати також на Опіллі, Подільській височині; щодо малих ВЕУ, то сприятливими вітровими умовами характеризується більша частина Івано-Франківської, особливо північні, північно-західні, південно-західні, східні райони (рис. 2).

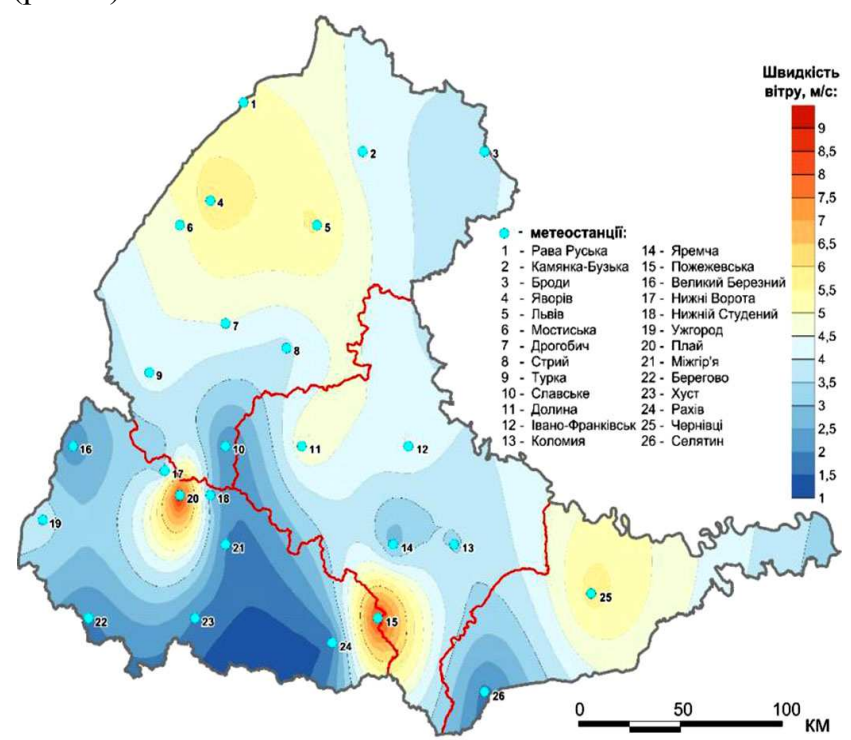

Рис. 2. Карта середньої швидкості вітру у Карпатському регіоні України на висоті 100 м

За результатами аналізу рельєфу з'ясовано, що в межах Івано-Франківської обл. ухил більше $25 \%$ мають гірські території, максимальні значення характерні для середньогір'я (Зовнішні Горгани, Чорногора, Гринявські гори, Чивчини). Тому, незважаючи на високі вітроенергетичні ресурси, рекомендовано виключати ці території з перспективних для розміщення ВЕУ. Ці обмеження не поширюються на ті території, для яких характерні менші ухили (гірські полонини, широкі річкові долини тощо), якщо вони не підлягатимуть іншим описаним нижче виключенням. Сприятливими орографічними умовами характеризуються Придністровське Поділля, Придністровське Покуття, Передкарпатська та Підгірська області.

Енергомережа Івано-Франківської обл. складається 3 ЛЕП та ПС 750, 400, 330 та 220 кВ, які входять до підпорядкування Укренерго, 110 кВ та нижчої напруги 
Прикарпаттяобленерго. Низька охопленість розподільчими мережами високої та середньої напруги віддалених гірських територій, зокрема Верховинського, частини Надвірнянського та Рожнятівського адміністративних районів, зменшує їх перспективність для впровадження вітроенергетики через збільшення витрат на підключення до енергомережі та екологічні впливи від будівництва доріг і ЛЕП на значні відстані.

В Івано-Франківській обл. налічується 517 територій та об'єктів ПЗФ загальною площею 221611,5 га (16 \% від території області), 3 них 33 площею 131696,1 газагальнодержавного значення. Найвищим відсотком заповідності характеризуються перспективні з огляду на вітрокліматичні ресурси території Яремчанської міської ради, Косівського та Верховинського р-нів, тому для уникнення впливів на території та види, що охороняються, рекомендуємо обмежити впровадження проектів 3 використанням енергії вітру на них.

Серед перспективних водно-болотних угідь міжнародного значення в межах Івано-Франківської обл. потенційно чутливою територією є Бурштинське водосховище та р. Дністер у межах Галицького НПП через найвищу концентрацію птахів на одиницю водної поверхні в регіоні, $є$ місцями регулярного перебування понад 20 тис. особин водоплавних птахів; місцями регулярного перебування понад 1 \% гоголя та до $25 \%$ української зимової популяції креха малого (Lisy IvanoFrankivshchyny, 2019). Щодо інших великих водних об'єктів, то на території області до великих річок належить Дністер з притоками в межах області - Свіча, Лімниця, Луква, Бистриця, Тлумач (праві), Гнила Липа (ліва); до середніх - Бистриця з притоками Бистрецею Надвірнянською та Бистрицею Солотвинською, Прут 3 притокою Черемош $з$ притоками Чорний Черемош і Білий Черемош.

В Івано-Франківській обл. лісовою рослинністю вкрито 41 \% території, однак ліси розміщенні нерівномірно та розташовані здебільшого в гірських умовах (73 \% - гірські ліси) (Upravlinnia statystyky, 2019). На території Івано-Франківської обл. є найцінніші ліси України - букові праліси Карпат, які внесено до переліку об'єктів Всесвітньої спадщини ЮНЕСКО.

Щільність населення Івано-Франківської обл. становить 99 осіб на км², що вище від середнього показника по Україні, у розподілі населення області за типом поселень переважає сільська місцевість (56 \%). Природні умови (рельєф, ліси) впливають на низьку щільність населення у Верховинському (24 ос/км²), Яремчанській міській раді (35 ос/км²) Рогатинському (49 ос/км²), Долинському (55 ос/км² ${ }^{2}$, Рожнятівському (56 ос/км $\left.{ }^{2}\right)$ рнах (United States, 2019).

Унаслідок отриманих даних для практичної реалізації алгоритму вибору майданчика для розташування BEC на місцевому рівні досліджуваною територією вибрано північно-західну частину Івано-Франківської області, а саме: територію Болехівської міської ради, Долинського, більшої частини Рожнятівського та західної частини Калуського районів. Вибір пояснюють тим, що в межах Івано-Франківської обл. після Карпатських середньогірних районів, використання яких обмежується орографією, віддаленістю від мереж, високою концентрацією об'єктів ПЗФ та лісистістю, ця територія характеризується найсприятливішими вітрокліматичними умовами. Окрім цього, у Долинському районі у грудні 2017 р. введено в експлуатацію першу чергу BEC Шевченкове-1, яка $\epsilon$ першою ВЕС в Івано-Франківській обл., а в Рожнятівському планується будівництво ВЕС потужністю 25 МВт та 15 км ЛЕП 110 кВ ТОВ "ВЕС Прикарпаття". Зважаючи на це доцільним $є$ встановлення відповідності вибраних майданчиків під дані $\mathrm{BEC}$ з перспективними на основі екологічно безпечного геопросторового планування.

Накладанням покомпонентних карт побудовано комплексну карту геопросторових обмежень (рис. 3), а подальшим їі накладанням на карту середньої швидкості вітру на висоті 100 м (див. рис. 2) - карту перспективних майданчиків розташування ВЕС (рис. 4).

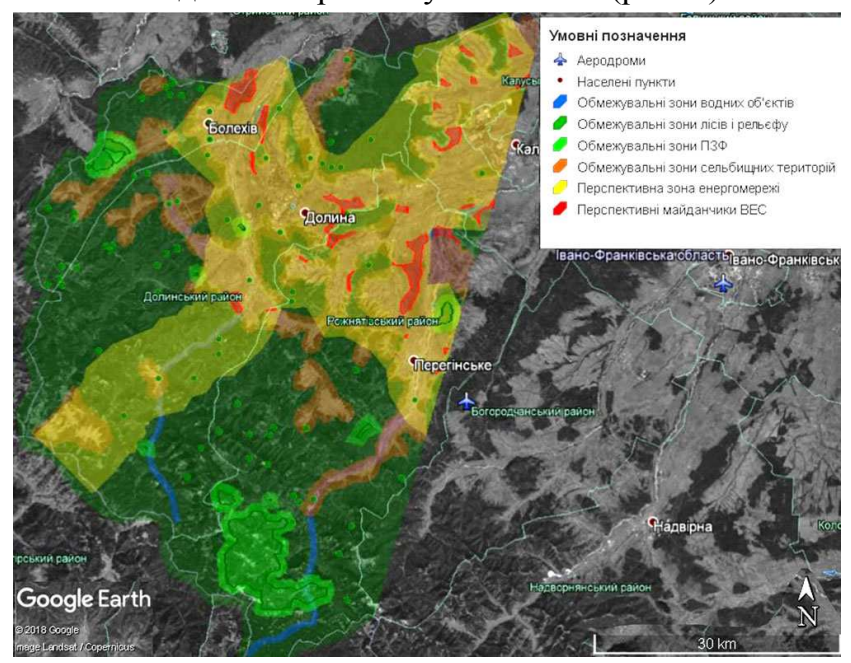

Рис. 3. Карта геопросторових обмежень досліджуваної теритоpiï

Виділено 24 безпечні перспективні майданчики розташування ВЕС загальною площею 4514,22 га. За результатами аналізу відповідності отриманих перспективних майданчиків 3 вибраними для реальних ВЕС, 3'ясовано, що територія ВЕС "Шевченкове-1" і планованої ВЕС у межах Цініської сільської ради входять до перспективних.

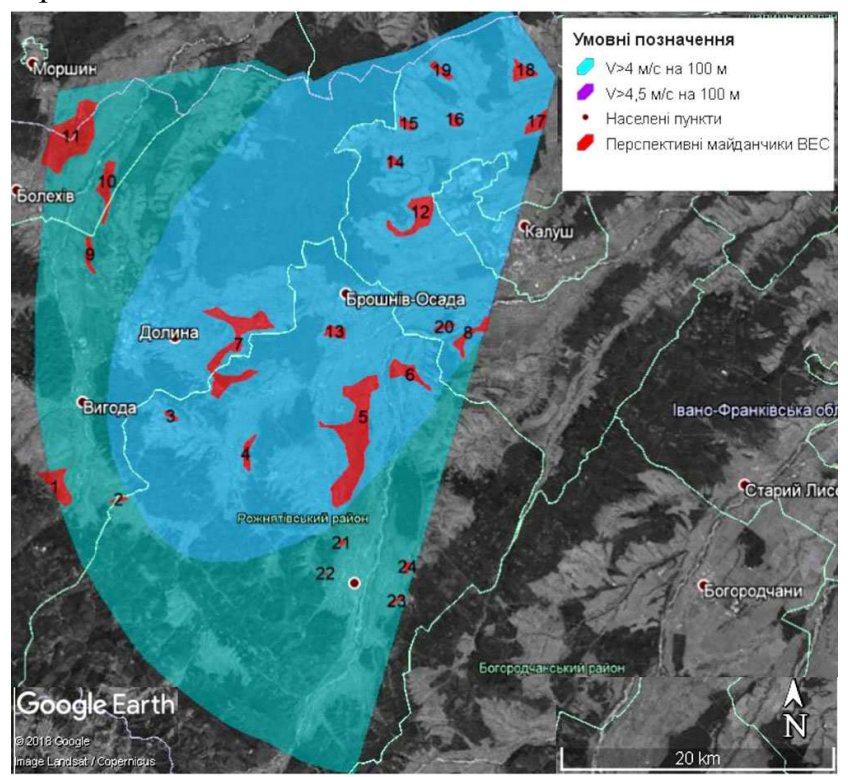

Рис. 4. Карта перспективних майданчиків розташування ВЕС досліджуваної території

Хоча майданчики ВЕС можуть мати різні площі та конфігурації, типова відстань між ВЕУ становить 310 діаметра турбін, а загальні потреби в території під $\mathrm{BEC}$, залежно від типу підстильної поверхні, змінюють- 
ся в широких межах та становлять для рівнинних відкритих територій в середньому 32 га на 1 МВт встановленої потужності, для ВЕС на схилах чи на залісених територіях - 18 га/МВт (United States, 2019). Зважаючи на площу та природні особливості майданчиків, загальна встановлена потужність для максимальної кількості BEУ Vestas V112 3.3 MBт - 88 одиниць становитиме 290,4 МВт. Достатня кількість різних за площею перспективних території дасть змогу отримати раціональне впровадження як малих, так і великих вітроенергетичних проектів 3 максимальною вигодою та мінімальною шкодою довкіллю.

Висновки. Удосконалено алгоритм вибору майданчика для розташування ВЕС шляхом застосування ГІСпідходу, який охоплює вибір досліджуваної території зі сприятливими кліматичними умовами за результатами оцінки вітроенергетичного потенціалу, врахування геопросторових обмежень на досліджуваній території та виділення перспективних майданчиків розташування BEC. Обгрунтовано врахування трьох типів обмежень: орографічних, технічних та природних екологічних та соціально-економічних шляхом встановлення геопросторових виключень і екологічно безпечних відстаней. Апробовано застосування алгоритму геопросторового планування майданчика для розташування ВЕС для Івано-Франківської області. Виділено безпечні перспективні майданчики розташування ВEC та порівняно їх 3 місцями розташування наявних і планованих ВЕС. Розраховано можливу потужність ВЕС на перспективних майданчиках.

\section{Перелік використаних джерел}

A Guideline Report. (2012). Environmental Impact Assessment for Wind Farm Developments. Retrieved from: http://www.cedroundp.org/content/uploads/publication/141010033252636 Environment Impact Assessment for Wind Farm Developments.pdf.

Base Final Report. (2014). Update of UK Shadow Flicker Evidence Base Final Report. Retrieved from: https://assets.publishing.service.gov.uk/government/uploads/system/uploads/attachment data/file/48052/1416-update-uk-shadow-flicker-evidence-base.pdf
DBN V.1.1-24:2009. (2009). Zakhyst vid nebezpechnykh heolohichnykh protsesiv, shkidlyvykh ekspluatatsiinykh vplyviv, vid pozhezhi. Osnovni polozhennia proektuvannia. Retrieved from: http://dbn.co.ua/load/normativy/dbn/dbn_v_1_1_24_2009/1-1-0786. [In Ukrainian].

DBN V.1.1-31:2013. (2013). Zakhyst terytorii, budynkiv i sporud vid shuти. Retrieved from: http:/www.acoustic.ua/img/pdfs/pdffile 131.pdf. [In Ukrainian].

DSP 173-96. (2013). Derzhavni sanitarni pravyla planuvannia ta zabudovy naselenykh punktiv. Baza danykh "Zakonodavstvo Ukrainy". VR Ukrainy. Retrieved from: http://zakon.rada.gov.ua/laws/show/z0379-96. [In Ukrainian].

Hötker, H. (2006). The impact of repowering of wind farms on birds and bats. Bergenhusen. Retrieved from: https://bergenhusen.nabu.de/imperia/md/images/bergenhusen/impa ct of repowering.pdf

Kuzmenko, E. D., Shtohryn, L. V., \& Chepurnyi, I. V. (2014). Analiz vplyvu heolohichnoi budovy hirskykh porid na kharakterystyky zsuviv. Heodynamika, 2, 112-124. [In Ukrainian].

Lisy Ivano-Frankivshchyny. (2019). Ivano-Frankivske oblasne upravlinnia lisovoho ta myslyvskoho hospodarstva. Retrieved from: http://www.ifforestry.gov.ua/lisi-ivano-frankivshchini. [In Ukrainian].

Ramsar 02.02.1971. (2013). Konventsiia pro vodno-bolotni uhiddia, shcho maiut mizhnarodne znachennia, holovnym chynom yak seredovyshche isnuvannia vodoplavnykh ptakhiv. Baza danykh "Zakonodavstvo Ukrainy". VR Ukrainy. Retrieved from: https://zakon.rada.gov.ua/laws/show/995 031. [In Ukrainian].

Turbine blades. (2014). Ice ejection from rotating wind turbine blades. Ground impact probability distributions and danger level estimate. Sweden: Björn Montgomerie. Povitrianyi kodeks Ukrainy. Baza danykh "Zakonodavstvo Ukrainy". VR Ukrainy. Retrieved from: http://zakon.rada.gov.ua/laws/show/3393-17. [In Ukrainian].

Uhiddia Ukrainy. (2019). Vodno-bolotni uhiddia Ukrainy. Retrieved from: http://wetlands.biomon.org/

United States. (2019). Land-Use Requirements of Modern Wind Power Plants in the United States. National Renewable Energy Laboratory. Retrieved from: https://www.nrel.gov/docs/fy09osti/45834.pdf

Upravlinnia statystyky. (2019). Holovne upravlinnia statystyky v Ivano-Frankivskii oblasti. Retrieved from: http://www.ifstat.gov.ua/. [In Ukrainian].

Zakon Ukrainy. (2012). Pro pryrodno-zapovidnyi fond Ukrainy. Baza danykh "Zakonodavstvo Ukrainy". VR Ukrainy. Retrieved from: https://zakon.rada.gov.ua/laws/show/2456-12. [In Ukrainian].

\section{N. M. Moskalchuk, Ya. O. Adamenko \\ Ivano-Frankivsk National Technical University of Oil and Gas, Ivano-Frankivsk, Ukraine}

\section{THE WIND FARM SITE SELECTION ON GIS-BASED APPROACH}

The environmentally safe site planning for wind farm based on the geospatial constraints is important to avoid obstacles to planned activities, environmental impacts, or public discontent. The study proposes the algorithm of wind farm site selection using the GIS-approach, which consists of three stages. Firstly, it is the choice of the study area with favourable climatic conditions based on the results of the wind energy potential assessment. Secondly, considering the geospatial constraints on the study area by collecting data, analyzing and mapping of environmental components that may be affected by wind farms (relief, road and energy network, nature reserve areas, water bodies, forests, settlements, airports) and identifies the criteria for geospatial constraints and their graphical representation in the form of component maps of orographic, technical, environmental constraints and a comprehensive map of geospatial constraints. The third stage allocates the feasible sites for the wind farms by mapping perspective wind speeds at a given height and maps of geospatial constraints. Three types of constraints are theoretically considered to be as follows: orographic, technical (road network and grid) and natural ecological (nature reserve areas, water objects, forests) and socio-economic ecological (settlements, airfield) by establishing geospatial exclusions and environmentally safe distances. The proposed algorithm of site selection for wind farm is implemented in Ivano-Frankivsk Region and the results are compared with the locations of existing and planned wind farms. The complex map of geospatial constraints of the territory with favourable wind-climatic conditions is developed by using the criteria of geospatial constraints. Then this map is utilized together with the wind speed map of the Carpathian region at a height of $100 \mathrm{~m}$ to identify environmentally safe feasible wind farm sites within the study area. As a result, the map of the feasible sites of the wind farms is developed and the potential powers of the wind farms on these sites are calculated.

Keywords: geospatial planning; GIS-approach; wind energy potential; geospatial constraints; wind farm; feasible sites. 